Journal

of Geography,

Politics and Society

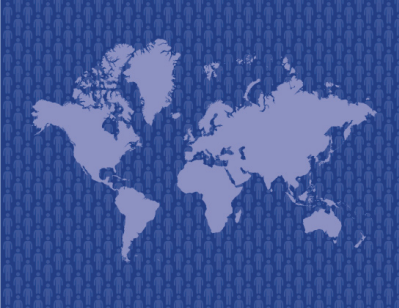

$10(1) / 2020$

\section{Journal of Geography, Politics and Society}

2020, 10(1), 33-41

https://doi.org/10.26881/jpgs.2020.1.05

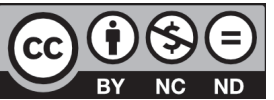

\title{
KURDISTAN'S ROLE IN EUROPEAN ENERGY SECURITY
}

\author{
Hemin Mohammed Ismael \\ Department of Geography, Faculty of Arts, Soran University, Kawa 44002, Soran, Erbil, Kurdistan Region - Iraq, \\ e-mail: hemn.ismail@soran.edu.iq
}

\section{Citation}

Ismael M.H., 2020, Kurdistan's role in European energy security, Journal of Geography, Politics and Society, 10(1), 33-41.

\begin{abstract}
The paper analyzes the Kurdistan Regional Government's (KRG) natural resource strategies, such as how it deals with huge reserves of many trillion cubic feet of its natural gas as significant energy. Because natural gas belongs to the cleanest burning fossil fuels, with 30 percent less carbon than oil, it plays a role in the global fuel economy. As KRG transports its natural gas to international markets, like European countries, via Turkey it means they also participate in energy security as a new actor. Because the KRG is landlocked, strong factors may affect Kurdish natural gas strategies because KRG is surrounded by today's partners and yesterday's enemies politically and economically. Turkey, the neighbor of KRG, also buys its gas and has an influence on these strategies after the Ukraine crisis that pushed European countries to make a turn towards Caspian natural gas. Kurdistan is part of the best option for European energy security as it plans to diversify natural gas imports. While the KRG benefits from selling its natural gas directly to international markets, this will come with some struggles. Many of these obstacles can be classified into two types: internal and external obstacles, such as a conflict with the central government regarding how to share gas revenues. Others problems include Iranian neighbor interest on natural resources in Kurdistan and Russia that looks to Kurdish gas as its ally if Kurdistan joins the southern gas corridor pipeline.
\end{abstract}

\section{Key words}

Kurdistan Region, Iraq, European Energy Security, natural gas.

Received: 11 December 2019

Accepted: 16 March 2020

Published: 31 March 2020

\section{Introduction}

Geographically, the Kurdistan Region refers to the three governorates: Duhok, Erbil, and Sulaymaniyah, which are governed by the KRG. In addition, the Kurdistan Region claims the three so-called disputed territories: Nineveh, Kirkuk, and Diyala, as well as the Makhmur District (fig. 1). With a population of 5.2 million that covers approximately 40,000 square kilometers, the Kurdish region is larger than the Netherlands and four times the area of Lebanon
(The Kurdistan Region in Brief, 2018). According to K. Hawrami (2016), the KRG region had an estimated 45 billion barrels of oil reserves (Mills, 2016). If true, this meant that if the KRG region were independent, it would possess the world's sixth-largest oil reserve. The KRG also has a potential of some 100-200 trillion standard cubic feet of natural gas (Gunter, 2011). Given the Kurdistan geostrategic importance, located between Europe and Asia, and especially with huge natural resource (oil and gas), it could become a central new actor in European energy security. In 


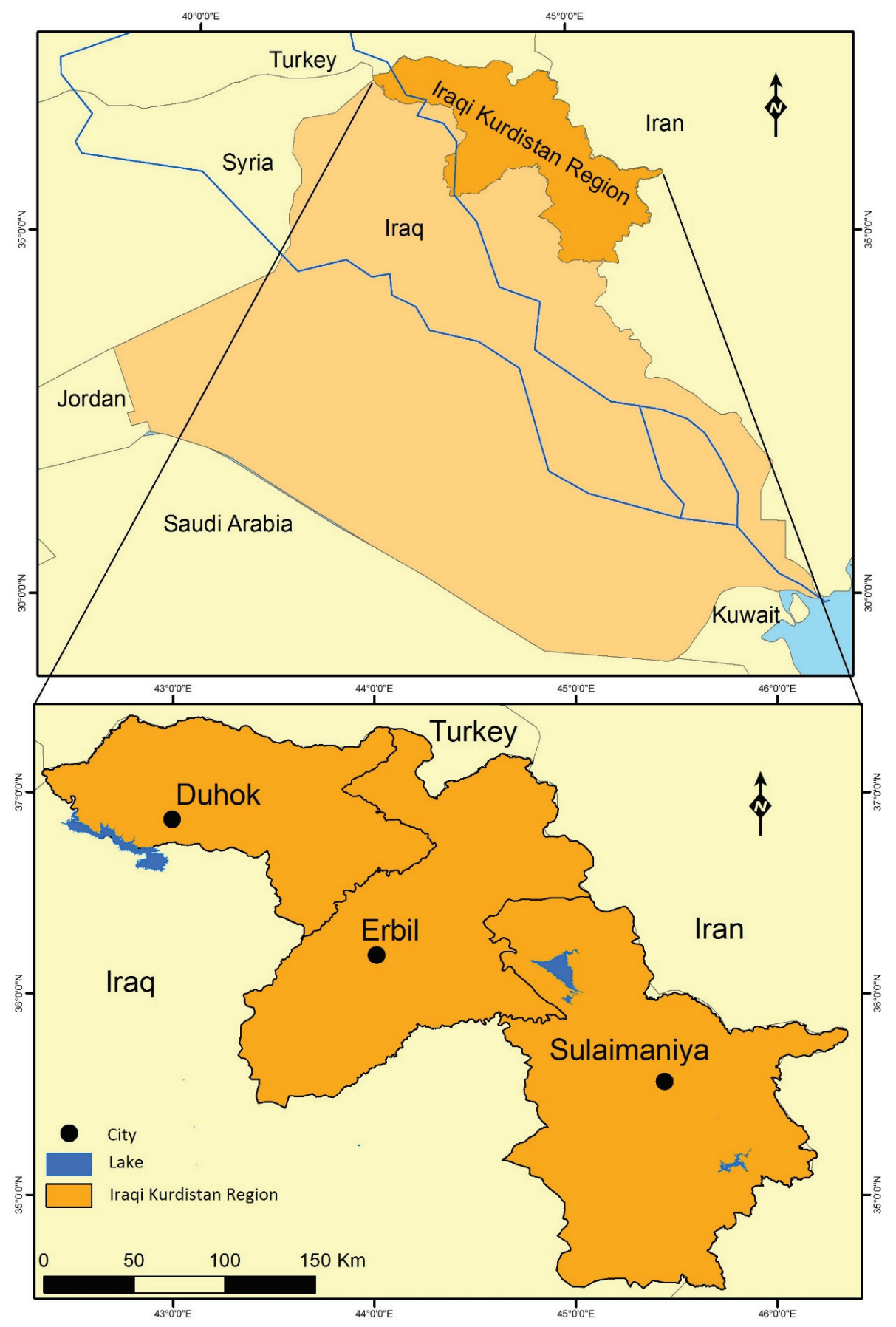

Fig. 1. Kurdistan region

Source: own study.

spite of the political instability in Iraq, a possibility of exporting Kurdistan gas reserve to Turkey and then to the European market has recently appeared. This is why the Iraq government as well as the Kurdistan Region Government (KRG) is discussing exporting Kurdistan gas to the European market through Turkey. Turkey and Azerbaijan are two countries that are more related to Kurdistan gas exporting. Turkey wants Kurdistan gas and oil first as a transition route to Europe and also gets fulfill internal needs. Azerbaijan, as an emerging new provider to Europe, wants Kurdistan to participate in the trans-Anatolian natural gas pipeline to fill the gap in the Shah Deniz natural gas field pipeline, which was built to transport gas to southern European countries. Turkey has already talked with the Iraqi government to import gas for domestic use and as well as to transport gas to Europe (Austivk, Gulmira, 2016).

The biggest concern for the EU in the field of energy today is the security of supply and reducing Russia's monopoly in the European market. The EU has to diversify its external supplies by diversifying 
supplier countries and routes. The EU and the markets in Southeastern Europe would be the most important customers for Kurdish gas. Therefore, Kurdistan is a place that many international companies will invest in, especially oil \& gas companies from Europe and the United States. The huge oil and gas companies that entered Kurdistan, such as Exxon Mobil, Genel Energy and Gazprom, have signed agreements with the Kurdistan region. However, the Kurdistan region faces more challenges for oil and gas exploration and exploitation, including sharing revenue with the central government in Baghdad. Also, the Kurdistan region is geographically landlocked. This paper will analyze the importance of Kurdistan's natural resource plan (gas) and how to market its gas to European countries. Further, it will outline how Kurdistan could participate in the securing of energy to buyers in the West and discuss the obstacles and opportunities of the KRG plans.

\section{Kurdistan Hydrocarbon Strategies and its problems}

The Kurdistan Region of Iraq holds 2.8 trillion cubic meters of gas reserves - approximately five times more than Azerbaijani reserves - and at some point may be able to supply its gas to Europe (Okumuş, 2013). The Kurdistan Oil and Gas Law were approved by the Kurdistan Parliament in August 2007. Erbil, the capital of the Kurdish autonomous region, not only has a long history of tensions with the government in Baghdad, but it is currently in the midst of a dispute over territory, degrees of autonomy, its budget, and power as well as control over oil and gas reserves (Paasche, Howri, 2014). In terms of oil and gas law interpretation, the Kurdistan region and central governments have many conflicts. For example, Dr. Hawrami, minister of natural resources of the Kurdistan government, strongly maintained that Article 115 of the new Iraqi constitution states the supremacy of regional laws over federal laws. He also argued that Article 112 only permits the Iraqi government an administrative role confined to the handling, i.e. exporting and marketing, of the extracted oil and gas from the existing not new gas and oil fields. Despite this, the KRG has signed 37 contracts with 40 companies leading to $\$ 10$ billion of investment in exploration and production in the oil sector (Gunter, 2011). Among the most notable were the U.S. companies Marathon Oil and Murphy Oil, Exxon Mobil, the Spanish company Repsol, and the Chinese company Sinopec. Three refineries have been commissioned with a total capacity of 200,000 $\mathrm{b} / \mathrm{d}$. Three power plants have been built, providing
80 percent of the KRG's energy needs. Kurdish production can reach 1 million b/d by 2014. They have built an infrastructure to carry their energy resources to global markets with Turkey and they managed to sell their oil abroad. Moreover, in November 2013, the governments of Turkey and the KRG signed a gas sales agreement governing the export of natural gas from to the KRG to Turkey, as they expected in 2017 the KRG could export $4 \mathrm{bcm}$ and rising to 10 bcm by 2020 (Humeyra, Orhan, 2013). Therefore, the KRG's gas market is now the most attractive sector for Turkish companies like Genel Energy and BOTAS. Those actions make the central government inconvenienced, thus the central government blacklisted Turkish oil and gas companies, such as Genel Energy, for their involvement with the Kurdistan Regional Government (Chmaytelli, 2017).

In 2012 Iraq cut the Kurdistan budget which was $17 \%$ of all Iraqi budgets. Also, after Iraq objected to US buyers from Kurdistan, a court in Texas made the decision and rejected delivery of cargoes from tankers near Texas, which means the United States do not like Kurdistan selling oil and gas independently (Driver, Julia, 2014). Kurds are unlikely to wait for the approval of the central Iraqi government to sell their own gas, Iraqi Kurdistan region sell oil with the support of Obama' administration, but they don't hide their fear that oil will dispute in Iraq and would threaten the political and economical stability (Zhdannikov, et al., 2014). Other issues that Kurdistan has always been concerned about include the political stability and security in Iraq that makes more issues for gas and foreign oil companies. These include the threat of ISIS that controls vast swaths of Iraqi territory including oil and gas fields in Kirkuk and Ninawa, such as Khabz and Anzala, and also the religious and ethnic tensions. Additionally, the Kurdistan region leaves only Turkey to the north as a viable partner for the export of the KRG natural resources. $95 \%$ of the Iraqi budget $-13 \%$ of which goes to the KRG - literally flows from natural resources, thus making Iraq and the KRG classical rentier states' states (Gunter, 2011). In addition to the mentioned issues that make the KRG slow to progress in term of developing the gas and oil sector, there are other issues related to selling large volumes of natural resources that do not match. This begs the question as to where the rest of money is going and whether this will lead to less economic growth in Kurdistan. 


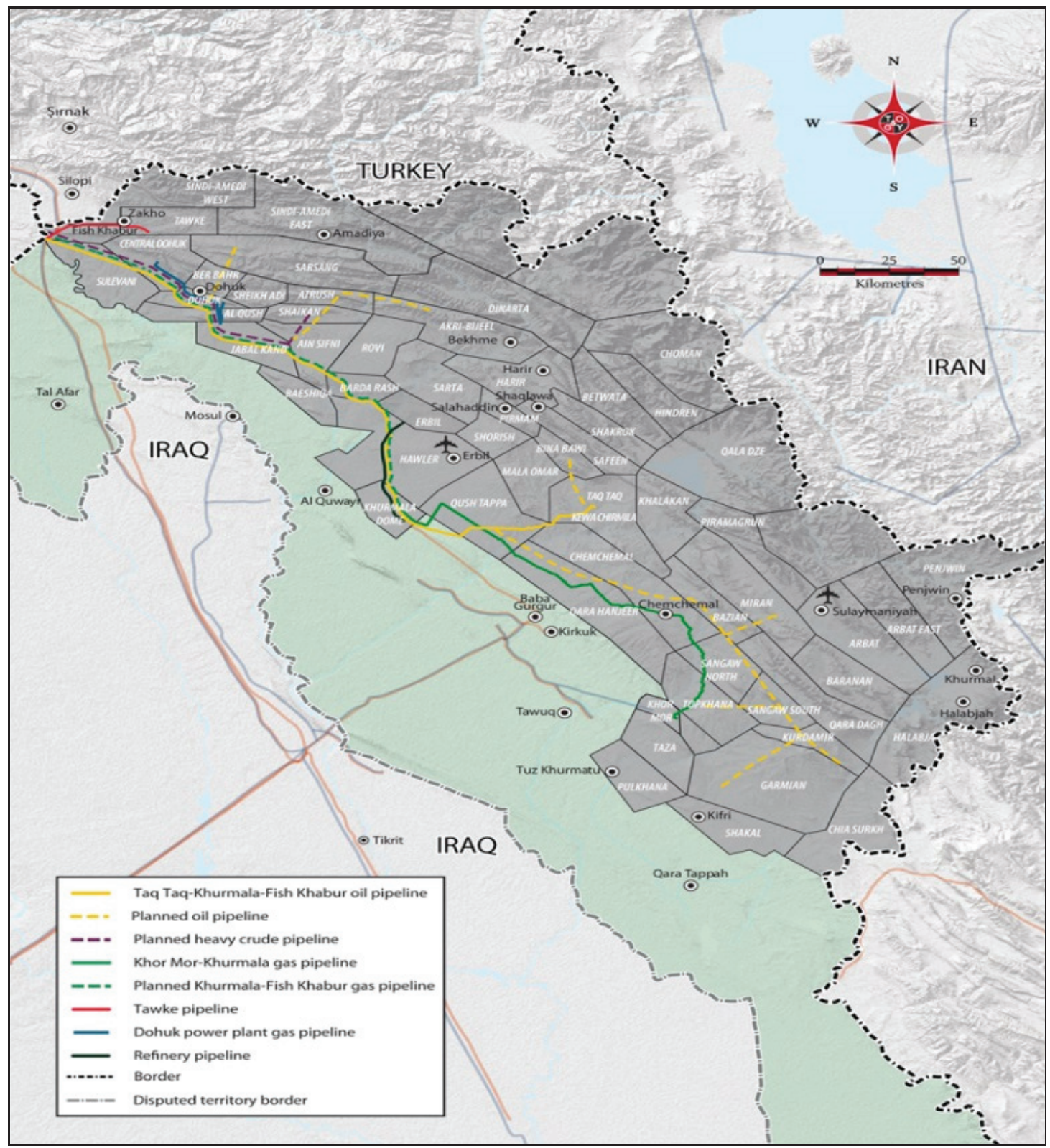

Fig. 2. Oil and gas infrastructure in Kurdistan

Source: Gas Pipelines..., 2015.

\section{Kurdistan region and marking gas to Europe via Turkey}

There are many factors as to why consumers around the world pay attention to Kurdistan gas. Ongoing events in Ukraine are raising concerns regarding the stable supply of gas to Europe. In 2016, Gazprom Export supplied 178.3 billion cubic meters of gas to European countries. Western European countries accounted for approximately $80 \%$ of the company's exports from Russia, while Central European states took 20\% (Gazprom Export 2018, 2018). But Europe's annual demand for additional gas import may reach 80 billion cubic meters by 2020 and surpass 140 billion cubic meters by 2030 (EU-U.S. Joint..., 2019). For that Europeans countries needs more gas, and other gas resources such as Kurdistan are one of the best options. According to data estimated by industry experts, the KRG has 45 billion barrels of oil and 99 trillion to 201 trillion cubic feet of gas. Even the distance of Kurdistan to European southern countries is close. Therefore, the European Countries searching for other alternatives may reduce their dependence on Russia's gas. In 2011 Tony Hayward, the former CEO of BP, described Kurdistan as "one of the last great oil and gas frontiers (Martin, 2017).

Kurdistan gas and oil will soon become one of the best options for many states in the west and the United States regarding security of energy. Overseas companies, such as the Turkish company Genel 
Energy, Norway's DNO BP, Total, China's petroleum, Russia's Gazprom, American Chevron and Exxon Mobil, had signed agreements with the Kurdistan region government. Turkey, Azerbaijan, and Iran also have interest in Kurdish gas marketing for many reasons. Nevertheless, the European countries will focus on Kurdistan oil and gas as good supplies in the near futures. They will start with the close neighbors to the KRG, the Turkish government, that decided to let the new Kurdish pipeline to tie up to its Ceyhan line. The Genel Energy Company has signed an agreement with KRG to develop two big gas fields, Miran and Bina Bawi, and is helping Kurdistan meet its commitments under an agreement to sell gas to Turkey by 2016-2017 (fig. 3). Turkey needs Kurdish gas for domestic use first because it is cheaper than what imported from Russia, Iran, and Azerbaijan, which means Turkey would secure a low price for gas. For Turkey it means cheaper access to natural gas and oil resources only $150-200 \mathrm{~km}$ from its border.

Turkey's energy costs are too high. Instead of paying an average of $\$ 450$ for 1,000 cubic meters of natural gas purchased from Russia, Iran, and Azerbaijan, Turkey will now be paying \$200-250 for this amount. Ankara and Erbil are reported to have agreed on a package of deals including gas exports.

Under the agreement, the KRG will sell gas to Turkey at the low price of $\$ 6-\$ 7$ per 1,000 cubic feet (cf), which is "attractive for Turkey given current purchase prices of as much as $\$ 12-\$ 14 \mathrm{cf}^{\prime \prime}$ (Roberts, 2016). Turkey as a new developing country needs more gas. The KRG appears as a new oil and gas market as many big and medium sized companies have begun to extract and invest in the Kurdistan region. Selling will need new routes, and Turkey is the best option for the KRG to export their natural resources to foreign markets. Therefore, a Turkish company is suited for the Kurdistan gas business in the long run, just as many other companies like BP did in the Caspian region two decades ago.

In the old maps of the original Nabucco gas pipeline plan, a southern gas supply leg to Northern Iraqi gas sources was represented by a dotted line. But with domestic tensions in Iraq and the Shah Deniz Consortium's strategic politics, this second leg disappeared (Okumuş, 2013). The Southern Gas Corridor project envisages the transportation of gas from the Caspian region through Georgia and Turkey to Europe. Kurdistan gas may link up with this project. The trans-Anatolian gas pipeline (TANAP) will be a central part of the southern gas corridor which will connect the Shah Deniz field in Azerbaijan to Europe. The construction of the pipeline formally began in March and was expected to be completed in 2018 (Austivk, Gulmira, 2016) (fig. 4). The State Oil Company of the Azerbaijan Republic, or SOCAR, has a 58\% stake in the project, with Turkey's state-owned Botaş holding 30\% and BP, operator of Shah Deniz, with the remaining $12 \%$. Appraisals for the cost of the pipeline's construction stand at around $\$ 10$ billion-11 billion (Work begins..., 2015). The Southern Gas Corridor is one of the EU's highest energy security priorities to reduce the Russian monopoly on gas marketing in Europe especially after the Ukrainian crisis. The transport of Kurdish gas to the Turkish market is planned to start by 2017 or 2018 . Over

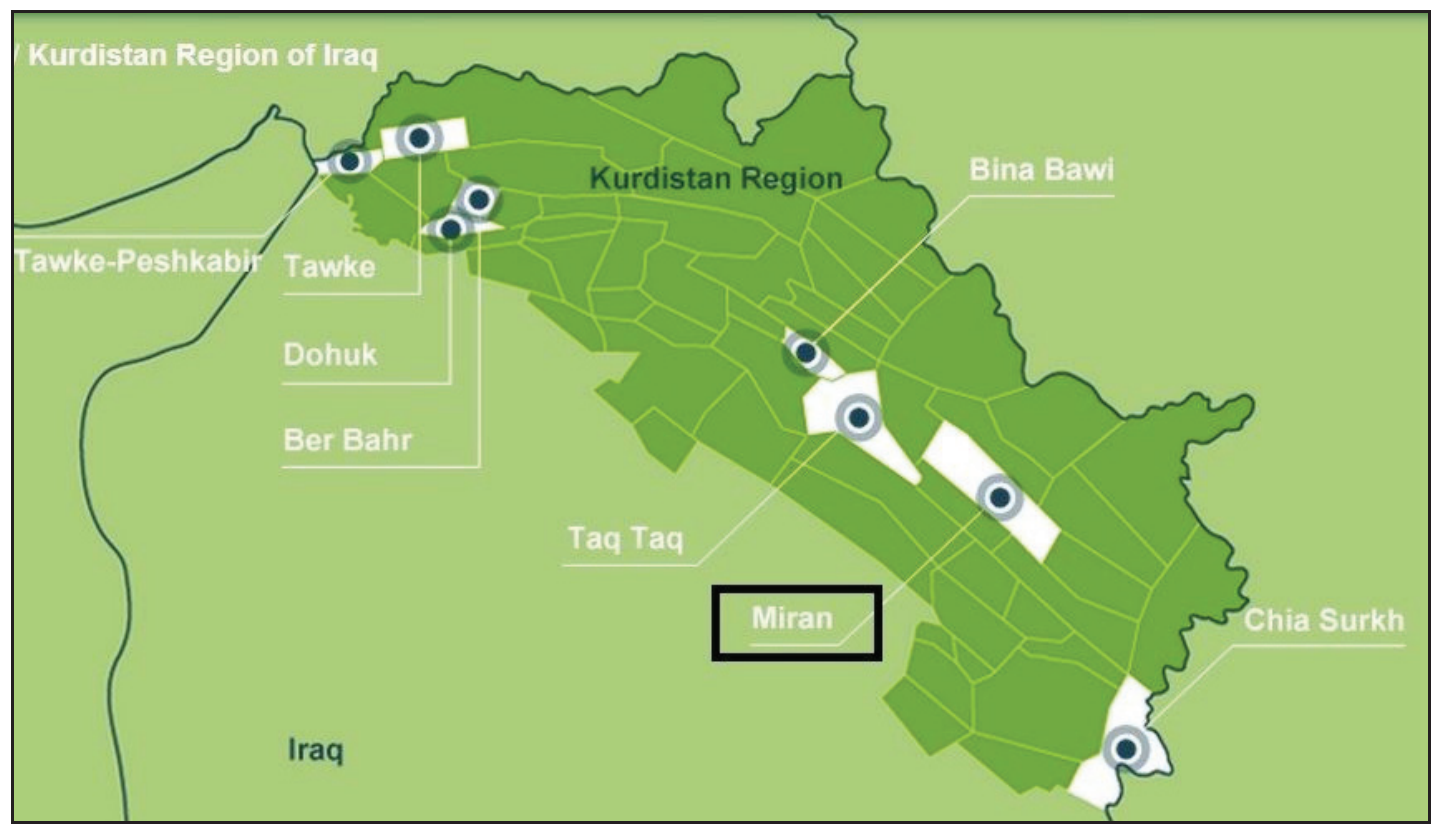

Fig. 3. Miran and Bina Bawi gas fields

Source: Genel gets..., 2018. 
20 billion cubic meters $(\mathrm{bcm})$ of Kurdish gas may be carried to the Turkish market by 2020, According to deputy head of the Natural Resources Committee in the Kurdistan Parliament, Kurdistan could fulfill 30\% of gas needs in Europe (Hawrami, 2016). Sha'ban continued, "Recently, we met with the French Consul in the Kurdistan Region who emphasized that France and Europe in general are hoping the Kurdistan Region's natural gas will fulfill a portion of their requirements" (Ismael, 2018). Experts speculated that the Kurdish gas infrastructure would not be ready by 2015. Even the Turkish pipeline corporation (BOTAS) according to some energy experts is not in a good condition in terms of capacity and delivery of Kurdistan gas to Europe (Austivk, Gulmira, 2016). Also, Hawrami said exports constituted the second stage of his government's gas policy, the first being to cater for the domestic demand.

The Kurdistan policy is to be self-sufficient as soon as possible, with any surplus gas going to the international market. The Kurdistan regional struggle against ISIS will make the crisis for Kurdistan push European countries to make more connections with Kurdistan, as for example, when Germany donated 13 million dollars to Kurdistan to support the Kurdish force Peshmerga. However, other political interests interpret this support as geopolitical because of energy in the region. So far, 28 countries have opened their consulates in Kurdistan, most of them being European countries, but also the United States and Russia. These countries are considering this move as a good opportunity of KRG to bypass Baghdad and its energy exports, and are making a symbolic step towards economic and political independence.

\section{Russia, Iran, and the KRG hydrocarbon plans}

Ongoing tension between Russia and European countries on the Ukraine crisis exists, with each of them looking for alternatives to buy gas. Ukrainian issues are pushing European countries to turn towards the Middle East for new gas resources and to reduce the Russia's gas monopoly. Russia was soon aware of the geopolitical importance of the Kurdistan region's resource. It opened a consulate in Erbil and sent its big oil and gas companies to the region, such as Lukoil and Gazprom. Gazprom signed agreements with the KRG to develop three gas fields in Garmian blocks of Halabja, Shakal and Qaradakh. Even if the KRG supplies natural gas to European countries by 2017 , it cannot completely substitute Russian natural gas unless Europe reduces their demand by $30 \%$. If 30 years ago the Russian and Iraqi governments had very good relationships in many aspects, economically and politically, especially during Iraq-Iran 8 years' war, this dilemma would not currently arise. The Russia's Lukoil oil and gas company has a big agreement with Baghdad to develop the West Qurna-2 field in Basra, which are big oil fields in southern Iraq that produce around 43 billion barrels of recoverable reserves, making it the second largest field in the world after Saudi Arabia's. This confuses Russia on how to deal with both the KRG and the central government at the same time. Some experts say if one wants Iraqi gas and oil, the interested parties should talk with Baghdad, but if they want delivery they have to talk with the KRG. Iraq with its ongoing instability crisis has difficulty in delivering its natural gas and oil without Kurdistan because gas and oil delivery is controlled by ISIS. ISIS controls the Turkey Yumurtalık Kirkuk-Ceyhan Oil Pipeline which is a 600 -mile (970 km) pipeline (fig. 5).

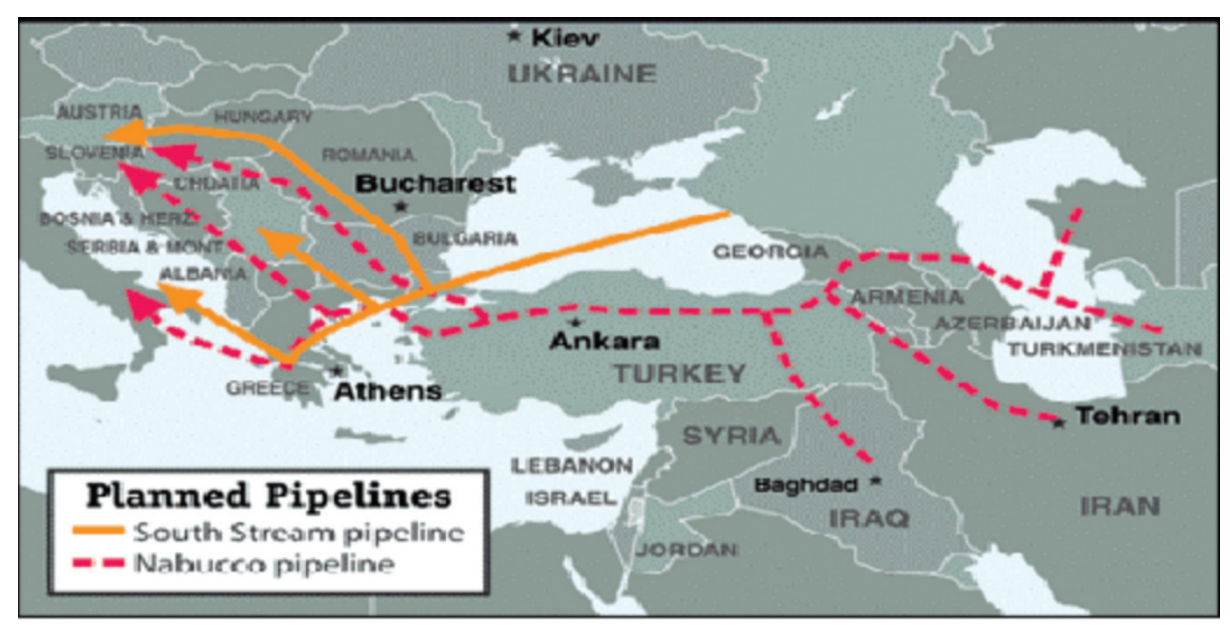

Fig. 4. Important gas pipelines from the Caspian region to Europe

Source: Mubaris, 2010. 
On 3 September 2013, the Iraq Petroleum Company reported that two bomb attacks halted the flow of crude oil through a severely damaged pipeline running from Iraq's Kirkuk oil fields to the Mediterranean port of Ceyhan in Turkey (Bomb..., 2013).

However, Iran is powerful and the nearest neighbor to Kurdistan, they stopped to observe natural resources in Iraqi Kurdistan region. Iran has more interests in Iraq's oil and gas due the approximate Iran has agreed to export 25 million cubic meters $(\mathrm{mcm})$ of gas a day to Iraq, and will start at seven $\mathrm{mcm}$ per day (Iran's..., 2018). In addition, for the same purpose, Kurdistan was visited by an Iranian delegation led by Ghasemi, head of the Iran-Iraq trade mission, and included Ardistani, advisor to Iran's oil minister, and Rafzani, head of Iran's national gas company (Kurdistan..., 2015). The KRG had talked to Iran to build a pipeline that would carry Iranian gas to Kurdistan to generate electricity and for domestic use especially in winter. In 2014, the KRG and Iran already agreed to build two pipelines from Iran to Kurdistan. The second one is for the KRG to export oil to Iran; in return, Iran would supply 3-4 million liters of fuel for power stations (Mills, 2016). Also, Iran has a hidden agenda in Kurdistan especially in the green zone area. This area is dominated by the Patriotic Union of Kurdistan (PUK) and has good ties with Iran rather than Kurdistan, which is led by president of the Kurdistan region, Masoud Barzani, and the Goran Movement. The reserves of natural gas in the Sulaymaniyah (zone area) province is $5 \mathrm{tcm}$, which is $80 \%$ of all reserve gas in the Kurdistan region. Iran wants dominance over KRG gas and oil strategies by dividing the Kurdistan region into two main zones, yellow and green; because they know that in 2017 Kurdistan will export gas to Turkey and Europe markets. I expect Iran will make all efforts before 2017 and make amendments to the KRG energy plan. In most events, Russia and Iran use gas as politics and it is to make pressure on Turkey and Europe. Russia is also looking to Kurdistan anxiously as a competitor and alternative to its Nabucco project. This means Russia's role in providing gas is likely to be replaced by the Kurdistan Region. All those deals and agreements that the KRG takes on the ground are not empty of challenges. For instance, it seems that Kurdistan Workers Party (PKK) is a big threat for Turkish gas and oil strategies. On Oct. 2013, gas exports from Iran were halted after an explosion at a pipeline in eastern Turkey near the Iranian border occurred in the early morning (Coskun, 2015). The PKK had repeatedly attacked pipelines in Turkey in the past. It is right that TANAP would be constructed in the north and far from the heart of the nationalist activity. The PKK remains active although gas pipelines from Iraq and Iran are embattled repeatedly.

There are solutions to secure gas in Europe if the southern gas corridor gets damaged inside Turkey. The Turkish government could hold negotiations with the PKK, which would give Kurdish people more rights and freedom. This may be better for Turkey and Europe not to be PKK's hostage. Even During the conflict between Armenia and Azerbaijan in the Nagorno-Karabakh region, the PKK conducted activity inside Azerbaijan, and they accusation against Armenia for supporting PKK leads to actual

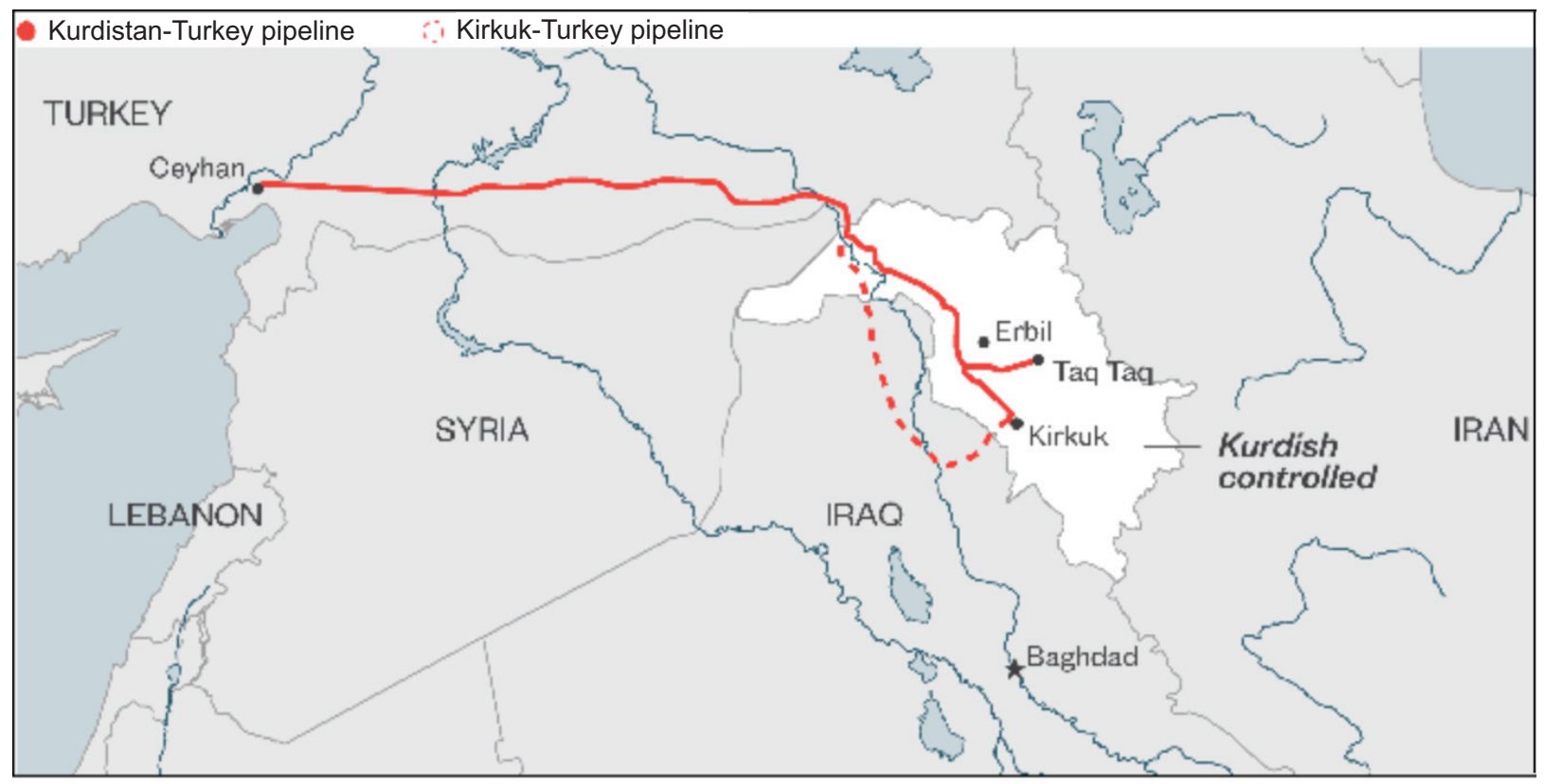

Fig. 5. Iraq-Turkey oil pipeline controlled by ISIS

Source: Lee, 2017. 
threatening toward gas and oil agreements. As a result, the August 2008 Baku-Tbilisi-Ceyhan (BTC) oil pipeline explosion in Refahiye, Turkey, occurred. The PKK, a militant pro-Kurdish organization, claimed credit for the explosion - which was plausible, because of the PKK's history of bombing pipelines and other Turkish infrastructure assets (2008 Turkish..., 2014). That means PKK activities in those areas may threaten the Turkish interests if no decision is made.

\section{Conclusion}

Until 2007, Kurdistan was considered a sleeping giant and is now awakening as an energy region in the Middle East. Kurdistan with huge reserves of gas and its geographic proximity to Europe, however, could become a crucial new actor in European energy security. The Kurdistan Region holds as much as $(5.67 \mathrm{bcm}$ ) of natural gas reserves, around $3 \%$ of the world's total reserves (The Kurdistan Region in Brief, 2018). However, there are issues that the Kurdistan natural resource-developing plan are facing, such as extracting and exporting gas to world markets. This is due to conflicts with central governments on the interpretation of some articles in the Iraq constitution related to the gas and oil law. Kurdistan being landlocked faces obstacles such as being highly dependent on the adjacent states, like Turkey, in exporting its gas. It is true the KRG has no real alternative export routes other than Turkey (Paasche, Howri, 2014). Also, some neighboring countries to Kurdistan may consider Kurdistan as an alternative to their natural resources, such as Turkey, Iran, Russia, and Azerbaijan. For example, the two neighbor countries, such as Iran and Turkey, have their own strategy to get benefits from natural gas resources in Kurdistan. Even Azerbaijan and some European countries have interest in Kurdistan natural resources. Azerbaijan and Turkey want Kurdistan gas for two different purposes, as Azeri need Kurdistan gas as supplement to Shah Denis gas fields that support most European gas needs by means of the Southern Gas Corridor. Turkey, however, wants Kurdish gas first for domestic use and to export to international markets. Iran is another neighbor of Kurdistan that has interests in Kurdistan gas and oil. Iran does not want Kurdistan to emerge as a new gas producer competing for gas markets in Europe. Therefore, Iran tries to dominate Kurdish natural resource strategies in many ways, such as creating problems between two big political parties that formed the government in Kurdistan. This includes their support for the PUK against the PDK, specifically against Masoud Barzani, the president of the Kurdistan region.
European countries also want Kurdish gas for many reasons; for example, the volume of Kurdish gas may make the Azerbaijan gas project succeed and make European less dependent on Russian gas. Therefore, many European gas companies have invested in the region. Ongoing crises in Kurdistan, such as the ISIS terrorist group, gave Europeans more pretenses to contribute to Kurdish strategies. Germany sent arms to Kurdistan to assist the force army Peshmerga, and they supported the KRG with 13 million dollars to fight wars against ISIS. If the KRG takes advantage of these changes in the relationships that occur in the Middle East, they may lead Kurdistan to become an independent economic power and make the region more prosperous.

\section{References}

Austivk G., Gulmira R., 2016, Turkey in the Geopolitics of Natural Gas, M-RCBG Associate Working Paper Series: Harvard University, Center for Business \& Government or of Harvard University, www.hks.harvard.edu/mrcbg (accessed:18 November 2019).

Bomb Attacks Halt Kirkuk-Ceyhan Oil Pipeline: Iraq Officials, 2013, Reuters: 21 August 2013, https://www.reuters. com/article/us-iraq-oil-pipeline/bomb-attacks-haltkirkuk-ceyhan-oil-pipeline-iraq-officials-idUSBRE97K09N20130821 (accessed:19 November 2019).

Chmaytelli M., 2017, Iraqi Government Asks Foreign Countries to Stop Oil Trade with Kurdist, Reuters: 24 September 2017, https://www.reuters.com/article/us-mideast-crisis-kurdreferendum-oil/iraqi-government-asks-foreign-countries-to-stop-oil-trade-with-kurdistan-idUSKCN1BZOYO (accessed: 18 November 2019).

Coskun O., 2015, Attack Halts Flow in Natural Gas Pipeline from Iran to Turkey, Reuters: 28 July 2015, https://www.reuters.com/article/us-turkey-gas-iran/gas-flow-in-turkeyiran-pipeline-halted-due-to-attack-minister-idUSKCN0Q20G820150728 (accessed:15 November 2019).

Driver A., Julia P., 2014, U.S. to Seize $\$ 100$ Million of Iraqi Kurdish Oil in Tanker off Texas, Reuters: 29 July 2014, https://www. reuters.com/article/us-usa-iraq-kurdishoil/u-s-judgesigns-order-to-seize-cargo-of-kurdish-oil-from-tankeroff-texas-idUSKBNOFYOKX20140729 (accessed: 18 October 2019).

EU-U.S. Joint Statement: Liquefied Natural Gas (LNG) imports from the U.S. continue to rise, up by $181 \%, 2019$, European Commission, https://ec.europa.eu/commission/presscorner/detail/es/IP_19_1531? (accessed: 12 February 2020).

Gas Pipelines, Kurdistan Regional Government, 2015, The Ministry of Natural Resources, http:// mnr.krg.org/index.php/ en/gas/gas-pipeline (accessed: 12 February 2018).

Gazprom Export 2018, 2018, http://www.gazpromexport.ru/ en/statistics/ (accessed:11 November 2019). 
Genel gets extension on Kurdistan gas fields, 2018, Pukmedia, https://www.pukmedia.com/EN/EN_Direje. aspx? Jimare $=42605$ (accessed $: 12$ February 2020).

Gunter M., 2011, Economic Opportunities in Iraqi Kurdistan, Middle East Policy, 18(2), 102-109. doi: 10.1111/j.14754967.2011.00488.x.

Hawrami K., 2016, KRG to Develop Natural Gas Production, Basnews, http://www.basnews.com/index.php/en/economy/kurdistan/303324 (accessed: 26 October 2019).

Humeyra P., Orhan C., 2013, Exclusive: Turkey, Iraqi Kurdistan Ink Landmark Energy Contracts, Reuters: 29 November 2013, https://www.reuters.com/article/us-turkey-iraq-oil/ exclusive-turkey-iraqi-kurdistan-ink-landmark-energycontracts-idUSBRE9ASOBO20131129 (accessed: 15 November 2019).

Iran's Gas Export to Iraq to Reach 50 Mcm/D, 2018, Financial Tribune: 11 February 2018, https://financialtribune.com/ articles/energy/81683/irans-gas-export-to-iraq-to-reach50-mcmd (accessed: 11 November 2019).

Ismael H.M., 2018, The Geopolitical Challenge of Iraqi-Kurdistan's Natural Gas, The University of North Carolina at Greensboro. https://libres.uncg.edu (accessed:10 March 2020).

Kurdistan Negotiating Gas and Oil Deals with Iran, 2015, Rudaw, http://www.rudaw.net/english/kurdistan/270220151 (accessed:12 October 2019).

Lee J., 2017, Politics and Unrest Kurdish Oil Tensions Show Iran Was a Trump Sideshow, https://www.bloomberg.com/ opinion/articles/2017-10-15/iran-s-a-distraction-the-urgent-problem-is-kurdish-oil (accessed:12 October 2019).

Martin B., 2017, Tony Hayward to Leave Troubled Genel Energy, http://www.telegraph.co.uk/business/2017/04/24/tonyhayward-leave-troubled-genel-energy/ (accessed: 10 October 2019).

Mills R., 2016, Under the Mountains: Kurdish Oil and Regional Politics, Oxford Institute for Energy Studies. https://www. oxfordenergy.org (accessed: 12 October 2019).

Mubariz R., 2010, Nabucco: Azerbaijan's increasing role in ensuring energy security of Europe. Available at: http://rahimlimubariz.blogspot.com/2010/06/nabucco-azerbaijansincreasing-role-in.html (accessed: 12 February 2020).

Okumuş O., 2013, Kurdistan's Natural Gas Resources May Become a Game-Changer over the Longer Term, European Energy Review. https://www.elektormagazine.com/ news/Kurdistan-s-natural-gas-resources-may-become-agame-changer-over-the-longer-term (accessed: 8 October 2019).

Paasche F., Howri M., 2014, Kurdistan Regional Government-Turkish Energy Relations: A Complex Partnership, Eurasian Geography and Economics, 55(2), 111-132. doi: 10.1080/15387216.2014.942339.

Roberts J., 2016, Iraqi Kurdistan Oil and Gas Outlook, Scribd, https://www.scribd.com/document/359054972/IraqiKurdistan-Oil-and-Gas-Outlook-Web-0915 (accessed: 1 October 2019).

Russia, Turkey Sign South Stream Pipeline Deal, 2009, Novinite. Com - Sofia News Agency, http://www.novinite.com/articles/106573/Russia\%2C+Turkey+Sign+South+Stream+Pi peline+Deal (accessed: 29 September 2019).
The Kurdistan Region in Brief, 2018, Kurdistan Regional Government, http://cabinet.gov.krd/p/page.aspx?l=12\&p=210 (accessed: 23 September 2019).

Work begins in Turkey on TANAP pipeline, 2015, The oil \& gas year, https://theoilandgasyear.com/news/first-pipelaid-for-trans-anatolian-natural-gas-pipeline/ (accessed: 12 February 2020).

Zhdannikov D., Isabel C., Ned P., 2014, Special Report: How Exxon Helped Make Iraqi Kurdistan, Reuters: 4 December 4 2014, https://www.reuters.com/article/us-mideast-crisis-kurdistan-specialrepor/special-reporthow-exxon-helped-make-iraqi-kurdistan-idUSKCNOJH18720141204 (accessed:12 February 2018). 